\title{
Cytogenetic Studies on the Effect of Insecticide Monocrotophos in Mouse Somatic and Germ Cells
}

\author{
Aziza A. E. Ibrahim* \\ Department of Genetics and Cytology, National Research Centre, Dokki, Cairo, Egypt \\ Received August 9, 2005; accepted August 23, 2005
}

\begin{abstract}
Summary The ability of pure insecticide "Monocrotophos" to induce chromosomal abnormalities in mouse somatic and germ cells was investigated. Male swiss mice were treated by gavage with the doses $0.05,0.1$ and $0.2 \mathrm{mg} / \mathrm{kg}^{-1}$ body wt. Samples were taken 6,24 and $48 \mathrm{~h}$ after treatment.

The percentage of chromosomal aberrations increased by increasing the concentrations of the insecticide and reached its maximum $24 \mathrm{~h}$ following oral treatment in both somatic and germ cells. In splenic cells, it reached $24.8 \pm 0.73$ and $17.8 \pm 0.86(p<0.01) 24 \mathrm{~h}$ after treatment with highest and lowest doses of the insecticide respectively compared with $26.2 \pm 1.02(p<0.01) 24 \mathrm{~h}$ after i.p. injection with Mitomycin C at $1 \mathrm{mg} / \mathrm{kg}^{-1}$ body wt.

In primary spermatocytes at diakinesis metaphase I of meiosis, the percentage of chromosomal aberrations reached $21 \pm 0.71(p<0.01) 24 \mathrm{~h}$ after treatment with the highest dose of Monocrotophos.

The frequency of sister chromatid exchanges (SCE's) in mouse bone-marrow cells was dose dependent and statistically significant after treatment with all doses of Monocrotophos.

The insecticide significantly increased chromosomal aberrations in mouse spleen, bone marrow and spermatocyte cells. Royal jell decreased the percentage of the induced chromosomal aberrations in somatic and germ cells after treated by gavage.
\end{abstract}

Key words Genotoxicity, Monocrotophos, Chromosomal aberrations, Mouse.

Monocrotophos possesses abroad insecticidal activity. It is used to control insect pests affecting tomatoes (Chalfant 1973), potato (Bodhade et al. 1983), Sweet corn (Janes 1973), Sugar can (Varma et al. 1978). Monocrotophos is toxic to insects which attack cotton (Singh et al. 1986).

It proved to be toxic to soybean looper larvae Ottens et al. 1984), the banana aphid (Suresh and Regupathy 1986), common earth worm (Bharathi and SubbaRao 1986), mites (Radke and Aherkar 1987) and adult beetles (Gupta et al. 1990).

Bhunya and Behera (1988) tested the mutagenicity of Monocrotophos in mouse cytogenetic test system. Cytogenetic assays like somatic chromosome aberrations, micronucleus test and sperm shape abnormalities with different doses $(5,2.5$ and $1.25 \mathrm{mg} / \mathrm{kg})$ and different exposure times $(6$, 24,48 and $120 \mathrm{~h}$ ) and different routes (i.p., p.o. and SC). Relative sensitivity of cytogenetic assays was found to be as: sperm shape abnormality $>$ chromosome aberrations $>$ micronucleus test. Monocrotophos was found to be mutagenic.

Monocrotophos is genotoxic in the chick in vivo test system (Jena and Bhunya 1992) and in both somatic and germ-line cells of Drosophila (Tripathy and Patnaik 1992).

Monocrotophos induced SCE's positively in Chinese hamster ovary (CHO) and rat tracheal epithelial (RTE) cells (Wang et al. 1987). Monocrotophos induced a significant increase in mean comet tail-length at all the doses when compared to control in Tilapia mossambica (Saleha et al. 2001).

Monocrotophos induced various types of chromosomal aberrations in meristematic cells of capsicum and chlorophyll mutations were recorded in M2 generation (Devadas et al. 1987).

\footnotetext{
*Corresponding author, e-mail: farghaly5@yahoo.com
} 
Materials and methods

Animals

Male Swiss mice aged 8:10 weeks and weighted 27 \pm 2 gm obtained from a closed randombred colony at the National Research Centre, were used.

\section{Insecticide}

Purified "Monocrotophos" (purity 100\%) were kindly supplied by Prof. S.M.A.D. Zayed Department of Organic Chemistry, National Research Centre. The protective Royal Jell was obtained, and the tested concentration $1 \mathrm{mg} / \mathrm{kg}^{-1}$ body wt. was dissolved in distilled water.

\section{Doses and treatment}

The doses used in the present study were $0.05,0.1$ and $0.2 \mathrm{mg}$ Monocrotophos $\mathrm{kg}^{-1}$ body wt. dissolved in $(0.1 \mathrm{ml}$ corn oil) was administered by gavage. The mice were killed 6,24 and $48 \mathrm{~h}$ after treatment. Non-treated mice and the mice with the vehicle were used as controls, another group was intraperitoneal injected with $1 \mathrm{mg}$ "Mitomycin C" and used as positive control.

Mice were injected with colchicine $2-3 \mathrm{~h}$ prior to killing. The spleen was washed with RPMI medium and cut into small pieces. The cells were aspirated into a centrifuge tube and $0.07 \mathrm{M} \mathrm{KCl}$ was added. The cells were centrifuged at $1000 \mathrm{rpm}$ for $10 \mathrm{~min}$ and fixed in methanol-acetic acid $(3: 1)$. After fixation, the cell suspension was dropped onto clean slides, that were stained with Giemsa in phosphate buffer pH 6.8 (Amer et al. 1993), 100 well spreaded metaphases were analyzed for each animal.

The testes were removed and meiotic chromosomal aberrations were observed according to the air-drying technique of Evans et al. (1964). Slides were coded and 100 well spread metaphases were analyzed for each animal, scoring different types of aberrations.

The method of SCE's was described by McFee et al. (1983). Bone marrow cells were fixed and stained with fluorescence plus Giemsa method of Perry and Wolff (1974). Five animals were taken for each treatment and control, 40 well spread metaphases per animal were examined.

The significance of the incidence of abnormalities in experimental versus control data was calculated using the $t$-test.

\section{Results}

Table 1 presents a detailed study of the effect of insecticide Monocrotophos on the induction of chromosomal aberrations in mouse spleen cells. The percentage of the induced aberrations increased by increasing the dose of Monocrotophos. It reached 17.8 \pm 0.86 and $24.8 \pm 0.73(p<0.01)$ $24 \mathrm{~h}$ after oral treatment by gavage with 0.05 and $0.2 \mathrm{mg} / \mathrm{kg}$ body wt. respectively. The mean percentage of metaphases with chromosome aberrations was found to be statistically significant after excluding gaps. It reached $16.0 \pm 0.71(p<0.01) 24 \mathrm{~h}$ with $0.1 \mathrm{mg} / \mathrm{kg}^{-1}$ body wt.

Monocrotophos induced both structure and numerical chromosomal aberrations which represented by gaps, fragment and/or breaks, deletions and Robertsonian translocations. Some metaphases with more than one type of aberrations were appeared (Fig. 1a).

Table 2 represented detailed study of the effect of the insecticide on the induction of chromosomal aberrations in the metaphase I of mice spermatocytes. The percentage of the induced chromosome aberrations was highly significant and dose dependent, it reached its maximum $24 \mathrm{~h}$ after treatment with the different concentrations of Monocrotophos. Its highest value was $13.6 \pm 0.81$, 17.2 \pm 1.16 and $21.0 \pm 0.71(p<0.01) 24 \mathrm{~h}$ after treatment with $0.05,0.1$ and $0.2 \mathrm{mg} / \mathrm{kg}^{-1}$ body wt. of Monocrotophos respectively compared with $23.0 \pm 0.71(p<0.01) 24 \mathrm{~h}$ after i.p. injection with Mitomycin C. 


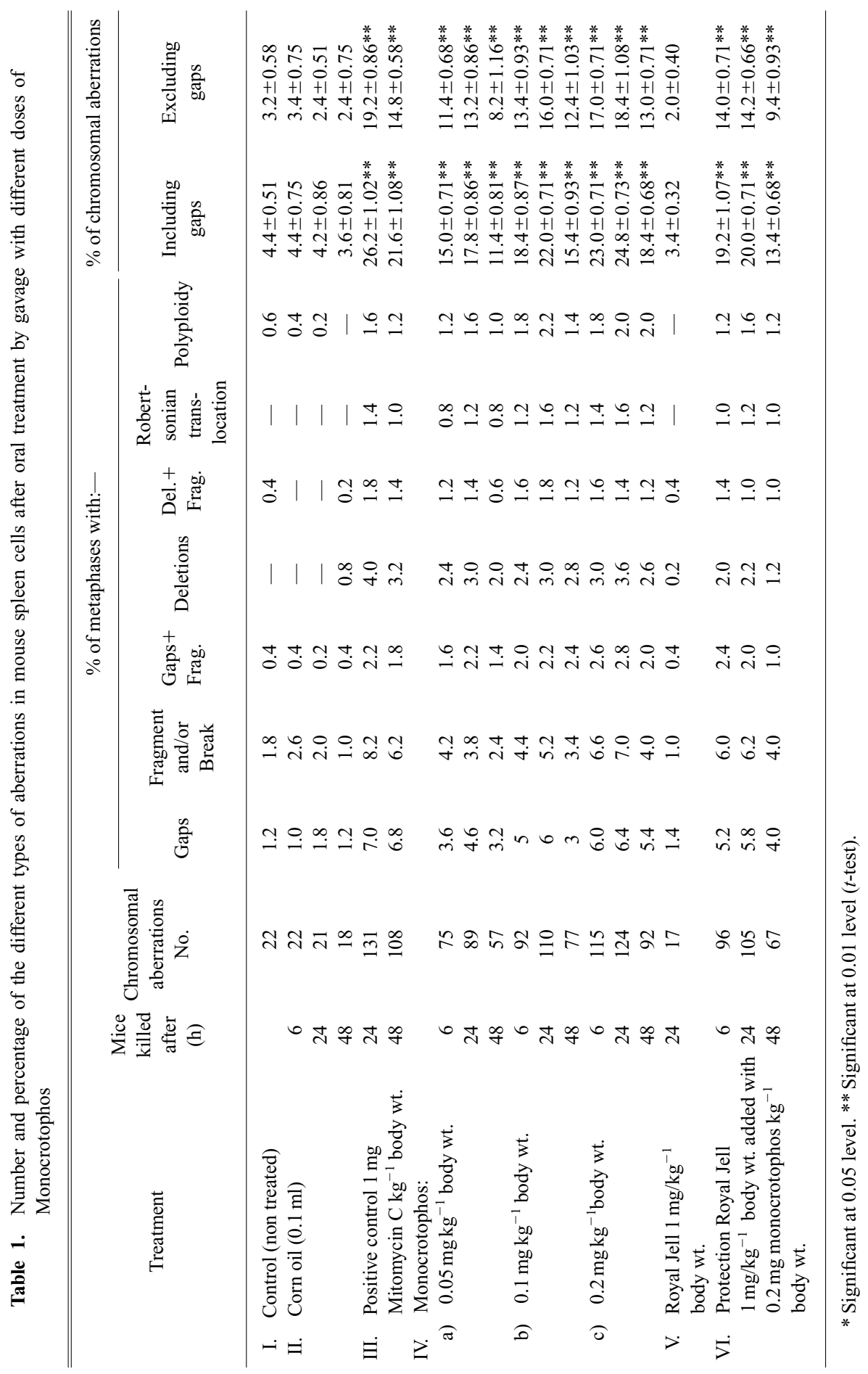


Monocrotophos induced abnormal chromosome associations including autosomal, $\mathrm{X}$ $\mathrm{y}$ univalent, fragments and/or breaks and chain IV (Fig. 1b, c).

Monocrotophos induced a significant and dose dependent increase in SCE's frequency in mouse bone-marrow cells. The frequency of SCE's/cell was found to be $14.62 \pm 0.93$ $(p<0.01)$ after oral treatment by gavage with the highest dose $\left(0.2 \mathrm{mg} / \mathrm{kg}^{-1}\right.$ body wt. $)$ compared with $3.71 \pm 0.51$ and $16.38 \pm 1.28$ for non treated and mitomycin $\mathrm{C}$ respectively (Table 3, and Fig. 1d).

It was observed that the percentage of abnormalities in spleen, spermatocyte and bone marrow cells in mice treated with Monocrotophos decreased after post-treatment with the protective Royal Jell (Tables 1, 2, 3).

\section{Discussion}

The in vivo chromosome aberrations

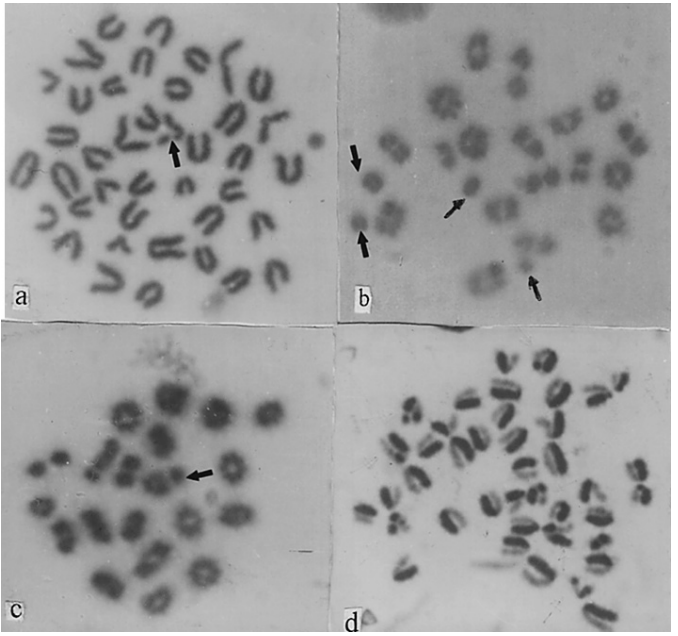

Fig. 1. Metaphases from mouse treated with different doses of "Monocrotophos" showing: a) chromatid gap in mouse spleen cells. b) A diakinesismetaphase 1 cell with X-y \& autosomal univalent and c) break in mouse spermatocyte. d) Metaphase from mouse bone-marrow cells showing SCE's induced after treatment with "Monocrotophos" insecticide. assay is one of the important bioassays for monitoring the genotoxicity of environmental chemical (AdHoc Committee 1972, Dulout et al. 1983 ) and it may be more useful in prediciting possible health risks. For this reasons, the in vivo test was used to study the genotoxic effect of the organophosphorous insecticide Monocrotophos.

Table 2. Number and percentage of the different types of metaphases with chromosomal aberrations in mouse spermatocyte cells after oral treatment by gavage with different doses of Monocrotophos

\begin{tabular}{|c|c|c|c|c|c|c|c|c|c|}
\hline & \multirow{2}{*}{ Treatment } & \multirow{2}{*}{$\begin{array}{l}\text { Mice } \\
\text { killed } \\
\text { after } \\
\text { (h) }\end{array}$} & \multirow{2}{*}{$\begin{array}{l}\text { Number of } \\
\text { abnormal } \\
\text { metaphases }\end{array}$} & \multicolumn{5}{|c|}{$\%$ of metaphases with: } & \multirow{2}{*}{$\begin{array}{c}\text { Mean \% of } \\
\text { abnormal } \\
\text { metaphase } \pm \text { S.E }\end{array}$} \\
\hline & & & & $\begin{array}{c}\mathrm{X}-\mathrm{y} \\
\text { univalent }\end{array}$ & $\begin{array}{c}\text { Autosomal } \\
\text { univalent }\end{array}$ & $\begin{array}{l}\text { X-y+ } \\
\text { A.U. }\end{array}$ & $\begin{array}{c}\text { Fragment } \\
\text { and/or break }\end{array}$ & Chain IV & \\
\hline I. & Control (non treated) & & 20 & 2.4 & 1.6 & - & - & - & $4.0 \pm 0.71$ \\
\hline \multirow[t]{3}{*}{ II. } & Corn oil $(0.1 \mathrm{ml})$ & 6 & 21 & 1.6 & 2.0 & 0.6 & - & - & $4.2 \pm 0.80$ \\
\hline & & 24 & 20 & 2.0 & 1.4 & 0.4 & 0.2 & - & $4.0 \pm 0.66$ \\
\hline & & 48 & 17 & 1.8 & 1.2 & 0.4 & - & - & $3.4 \pm 0.51$ \\
\hline \multirow[t]{2}{*}{ III. } & Positive control $1 \mathrm{mg}$ & 24 & 115 & 10.2 & 8.8 & 1.4 & 0.8 & 1.8 & $23.0 \pm 0.71 * *$ \\
\hline & $\begin{array}{l}\text { Mitomycin } \mathrm{C} \mathrm{kg}^{-1} \text { body wt. } \\
\text { IV. Monocrotophos: }\end{array}$ & 48 & 86 & 8.6 & 6.0 & 1.0 & 0.4 & 1.2 & $17.2 \pm 1.07 * *$ \\
\hline \multirow[t]{3}{*}{ a) } & $0.05 \mathrm{mg} \mathrm{kg}^{-1}$ body wt. & 6 & 60 & 6.0 & 5.2 & 0.2 & 0.2 & 0.4 & $12.0 \pm 0.71 * *$ \\
\hline & & 24 & 68 & 5.8 & 6.2 & 1.0 & 0.4 & 0.2 & $13.6 \pm 0.81 * *$ \\
\hline & & 48 & 46 & 4.4 & 4.0 & 0.6 & 0.2 & - & $9.2 \pm 0.86^{* *}$ \\
\hline \multirow[t]{3}{*}{ b) } & $0.1 \mathrm{mg} \mathrm{kg}^{-1}$ body wt. & 6 & 73 & 6.8 & 6.2 & 0.8 & 0.6 & 0.2 & $14.6 \pm 0.75 * *$ \\
\hline & & 24 & 86 & 7.4 & 5.0 & 1.0 & 0.4 & 0.4 & $17.2 \pm 1.16^{* *}$ \\
\hline & & 48 & 55 & 5.4 & 4.8 & 0.6 & - & 0.2 & $11.0 \pm 0.71 * *$ \\
\hline \multirow[t]{3}{*}{ c) } & $0.2 \mathrm{mg} \mathrm{kg}^{-1}$ body wt. & 6 & 92 & 8.0 & 7.0 & 1.4 & 1.0 & 1.0 & $18.4 \pm 0.75 * *$ \\
\hline & & 24 & 105 & 8.6 & 6.8 & 2.0 & 1.6 & 2.0 & $21.0 \pm 0.71 * *$ \\
\hline & & 48 & 61 & 5.4 & 5.0 & 0.8 & 0.4 & 0.6 & $12.2 \pm 0.86^{* *}$ \\
\hline $\mathrm{V}$. & $\begin{array}{l}\text { Royal Jell } 1 \mathrm{mg} / \mathrm{kg}^{-1} \\
\text { body wt. }\end{array}$ & 24 & 16 & 2.0 & 1.2 & - & - & - & $3.2 \pm 0.37$ \\
\hline \multirow[t]{3}{*}{ VI. } & Protection Royal Jell 1 & 6 & 65 & 5.0 & 6.0 & 1.0 & 0.6 & 0.4 & $13.0 \pm 0.71 * *$ \\
\hline & $\mathrm{mg} / \mathrm{kg}^{-1}$ body wt. added & 24 & 87 & 6.2 & 7.4 & 2.0 & 0.8 & 1.0 & $17.4 \pm 0.93 * *$ \\
\hline & $\begin{array}{l}\text { with } 0.2 \mathrm{mg} \text { monocrotophos } \\
\mathrm{kg}^{-1} \text { body wt. }\end{array}$ & 48 & 44 & 3.2 & 4.0 & 1.0 & 0.6 & - & $8.8 \pm 0.58 * *$ \\
\hline
\end{tabular}


Table 3. Frequency of sister chromatid exchange (SCE's) in mouse bone-marrow cells induced after oral treatment by gavage with different doses of Monocrotophos

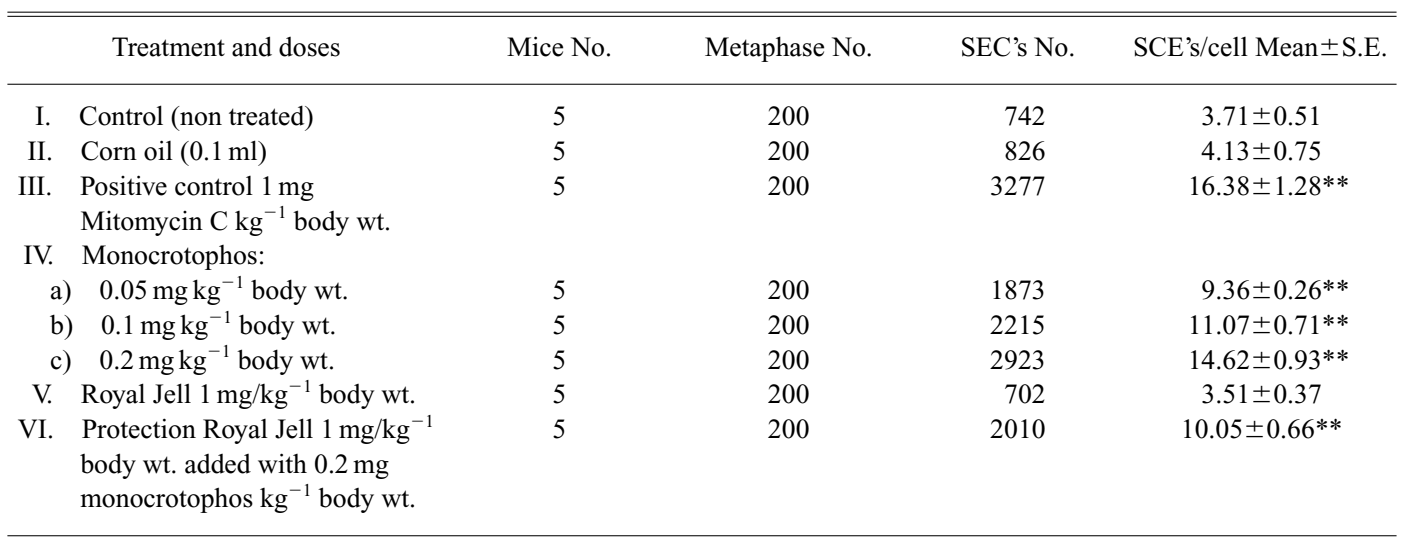

* Significant at 0.05 level. ** Significant at 0.01 level ( $t$-test).

Cytogenetic studies were performed on spleen, spermatocytes and bone marrow of the mouse, using oral treatment by gavage with the doses $0.05,0.1$ and $0.2 \mathrm{mg}$ Monocrotophos $\mathrm{kg}^{-1}$ body wt. The result indicated that the insecticide induced a high percentage of chromosome aberrations after all times of the treatment.

The percentage of the induced aberrations was dose dependent and it reached its maximum $24 \mathrm{~h}$ after the treatment with the different doses in somatic and germ cells. Monocrotophos induced a high percentage of chromosome aberrations in mouse spleen cell cultures and mouse bone-marrow (Ibrahim 1993). The same results obtained on Dicamba herbicide (Aly 1993), Dursban and Dichlorovos (Amer et al. 1998), Sevin (Amer et al. 2000b).

Bhunya and Jena (1993) observed that a significant induction of chromosome aberrations only after $24 \mathrm{~h}$ exposure with the highest dose $\left(5 \mathrm{mg} / \mathrm{kg}^{-1}\right)$ of Monocrotophos in the chick in vivo system test.

Richardson et al. (1984) reported that, when assessing the data derived from in vitro cytogenetic assays, it is usual to regard gaps as a separate category of damage and accord all other types of damage equivalent weights.

The percentage of chromosome aberrations inducced by Monocrotophos was found to be highly significant in mouse spleen cells after excluding number of metaphases with gaps. It reached $13.2 \pm 0.86,16.0 \pm 0.71$ and $18.4 \pm 1.08(p<0.01) 24 \mathrm{~h}$ after injection with $0.05,0.1$ and $0.2 \mathrm{mg}$ Monocrotophos $\mathrm{kg}^{-1}$ body wt. compared with $19.2 \pm 0.86(p<0.01) 24 \mathrm{~h}$ after intra-peritoneal injection with $1 \mathrm{mg}$ Mitomycin $\mathrm{C} \mathrm{kg}^{-1}$ body wt. The same results were obtained on Trifluralin herbicide (Ibrahim 1998). Numerical aberrations show a low percentage in the form tetraploidy.

Also, chromosome aberrations were observed in the primary spermatocytes of mice treated with insecticide. The most common type of aberrations was the presence of univalents. The X-y univalents were more often sperated than autosomes. The phenomenon was observed also by Imai et al. (1981) and $\mathrm{Hu}$ and Zhu (1990). Reciprocal translocations were present in the form of chain IV in a low frequency. This indicates that Monocrotophos induced chromosome damage in germ cells.

The types of chromosome aberrations induced with Monocrotophos were also observed in primary spermatocytes of mice treated with other pesticides having different chemical structures, for example the organophosphorus insecticide pirimiphos-methyl (Aly and Fahmy 1995), the pyrethroid insecticide fenvalerate (Amer et al. 2003a); in mice fed faba beans treated with the organophsophorous insecticide DDVP (Amer et al. 2000a); in mice fed stored wheat grains treated with the organophosphorous insecticide malathion (Amer et al. 2002) and the fungicide benomyl 
(Amer et al. 2003b).

Many carcinogens and/or mutagens are known to induces SCE's (Abe and Sasaki 1982, Fahmy 1999). The induced increase in SCE's frequency after treatment the bone-marrow cells with different doses of Monocrotophos was significant and dose-dependent, and the frequency of SCE's/cell reached $14.62 \pm 0.93$ after oral treatment with high dose of the insecticide.

The present results show that oral administration of Royal Jell $1 \mathrm{mg} / \mathrm{kg}^{-1}$ body wt. to mice treated with the highest dose of Monocrotophos $0.2 \mathrm{mg} / \mathrm{kg}^{-1}$ body wt. minimized the percentage of the induced chromosome aberrations and SCE's, the antimutagenic properties of Royal Jell have been demonstrated in vivo.

The positive results obtained from this study indicate that Monocrotophos is genotoxic in mouse somatic and germ cells. Also, the ability of Royal Jell to reduce the cytogenetic damage induced by the organophosphorous insecticide.

\section{References}

Abe, S. and Sasaki, M. 1982. SCE as an index of mutagenesis and/or carcinogenesis. In: Sandberg, A. A. (ed.). Sister Chromatid Exchange. Alan Liss, New York, pp. 461-514.

AdHoc Committee of the Environmental Mutagen Society and the Institute for Medical Research. 1972. Chromosome methodologies in mutation testing. Toxicol. Appl. Pharmacol. 22: 269-275.

Aly, F. A. E. 1993. Assessment of the genotoxicity of the herbicide "Dicamba" and the "Pirimiphos-methyl" in mouse bonemarrow and in mouse spleen cells in culture. Ph. D. Thesis, Department of Zoology, Faculty of Science, Cairo University.

— and Fahmy, M. A. 1995. Induction of chromosomal aberations in somatic and germ cells by the insecticide pirimiphosmethyl. Eqypt. J. Appl. Sci. 10: 312-324.

Amer, S. M., Ibrahim, A. A. E. and El-Sherbeny, K. M. 1993. Induction of chromosomal aberrations and sister chromatid exchange in vivo by the insecticide "Cypermethrin". J. App. Toxi. 13: 341-345.

- - - and Aly, F. A. E. 1998. Induction of chromosomal aberrations in mouse germ cells by the organophosphorus insecticides, "Dursban" and "Dichlorovos" and sperm abnormalities in the treated mice. Sci. Med., J. ESCME 10: $97-108$.

—, Aly, F. A. E. and Donya, S. M. 2000a. Cytogenetic effect of the organophosphorous insecticide DDVP and its residues in stored faba beans in somatic and germ cells of the mouse. Cytologia 65: 295-303.

-, Ibrahim, A. A. E., Aboul-Ela, E. I. and Farghaly, A. A. 2000b. Genotoxicity of the insecticide "Sevin" and of its residues in stored faba beans in mouse somatic and germ cells. Bull. NRC, Egypt 25: 281-295.

-, Fahmy, M. A., Aly, F. A. E. and Farghaly, A. A. 2002. Cytogenetic studies on t he effect of feeding mice with stored wheat grains treated with Malathion. Mutat. Res. 513: 1-10.

-, Aly, F. A. E. and Donya, S. M. 2003a. Genotoxicity of the pyrethroid insecticide fenvalerate tested in vitro and in vivo. J. Egypt. Soc. Toxicol. 29: 55-64.

-, Donya, S. M. and Aly, F. A. E. 2003b. Genotoxicity of benomyl and its residues in somatic and germ cells of mice fed on treated stored wheat grains. Arch. Toxicol. 77: 712-721.

Bharathi, C. and SubbaRao, B. V. S. S. R. 1986. Toxic effects of two organophosphate insecticides, "Monocrotophos" and "Dichlorovos", to common earthworm (Lampito mauritii). Water air soil pollut. 28: 127-130.

Bhunya, S. P. and Behera, B. C. 1988. Mutagenicity assay of an organophosphate pesticides, "Monocrotophos" in mammalian in vivo test system. Cytologia 53: 801-807.

- and Jena, G. B. 1993. Studies on the genotoxicity of monocrotophos an organophosphate insecticides, in the chick in vivo test system. Mutat. Res. 292: 231-239.

Bodhade, S. N., Salankar, B. S., Rajurkar, B. S. and Borle, M. N. 1983. Residual toxicity of some insecticides against potato aphid (Mazus persicae). PKV (Punjabrao Krishi vidyapeeth) Res. J. 7: 26-29.

Chalfant, R. B. 1973. Chemical control of the southern green stinkbug, tomato fruitworm and potato aphids on vining tomatoes in southern Georgia. J. GA Entomol. Soc. 8: 279-283.

Devadas, N., Sadanandam, A., Kishan Rao, R. and Subhash, K. 1987. Induced somatic aberrations and chlorophyll mutations in Capsicum by insecticides. Cytologia 52: 235-242.

Dulout, F. N., Pastori, M. C. and Olivero, O. A. 1983. Malathion induced chromosome aberrations in bone-marrow cells of mice: dose response relationship. Mutat. Res. 122: 163-167.

Evans, E. P., Breckon, G. and Ford, C. E. 1964. An air-drying method for meiotic preparation from mammalian tests. Cytogenetics 3: 289-294. 
Fahmy, M. A. 1999. Evaluation the genotoxicity of acrylonitrile in different tissues of male mice. Cytologia 64: 1-9.

Gupta, B. K., Ahmad, S. I. and Veer, V. 1990. Relative toxicity of some conventional insecticides against adult beetles of Calopepla Leoyana Latr, (Chrysomelidae: Coleoptera). Indian J. Agric. Res. 115: 430-434.

$\mathrm{Hu}, \mathrm{Q}$. and Zhu, S. 1990. Induction of chromosomal aberrations in male mouse germ cells by uranyl fluoride containing enriched uranium. Mutat. Res. 244: 209-214.

Ibrahim, A. A. E. 1993. Cytogenetic studies on the effect of the herbicide "Trifluralin" and "Monocrotophos" in mouse bone-marrow and spleen cells in culture. Ph. D. Thesis, Department of Zoology, Faculty of Science, Cairo University.

- 1998. Induction of chromosome aberrations in mice spleen and Germ cells by the herbicide "Trifluralin". Sci. Med. J. 10: $63-71$.

Imai, H., Matsuda, T., Shiroishi, Y. and Moriwaki, K. 1981. High frequency of X, y chromosome dissociation in primary spermatocytes of F1 hyprids between Japanese wild mice (Mus Musculus molosinus) and imbred Laboratory mice. Cytogenet. Cell Genet. 29: 166-175.

Janes, M. J. 1973. Corn earworm and fall armyworm occurrence and control on sweet corn ears in South Florida. J. Econ. Entomol 66: 973-974.

Jena, G. B. and Bhunya, S. P. 1992. Thirty day genotoxicity study of an organophosphate insecticide "Monocrotophos" in a chick in vivo system. In vivo 6: 527-530.

McFee, A. F., Lowe, K. and San Sebastian, J. R. 1983. Improved sister chromatid differentiation using paraffin coated bromodeoxyuridine tablets in mice. Mutat. Res. 119: 83-88.

Ottens, R. J., Todd, J. W., Herzog, G. A. and Bass, M. H. 1984. Toxicity of selected insecticides to Laboratory and field colonies of the soybean Looper (Pseudoplusis includens). J. Agric. Entomol. 1: 367-370.

Perry, P. and Wolff, S. 1974. New Giemsa method for the differential staining of sister chromatids. Nature 261: 156-158.

Radke, S. G. and Aherkar, S. K. 1987. Studies on the efficacy of some pyrethroids for control of the pests of chilli. (P. K.V. Punjabrao Krishi Vidyapeeth). Res. J. 11: 156-159.

Richardson, C. R., Howard, C. A., Sheldon, T., Wildgoose, J. and Thomas, M. G. 1984. The human lymphocyte in vitro cytogenetic assay positive and negative control observations of 30000 cells. Mutat. Res. 141: 59-64.

Saleha Banu, B., Danadevi, K., Rahman, M. F., Ahyja, Y. R. and Kaiser, J. 2001. Genotoxic effect of "Monocrotophos" to sentinel species using comet assay. Food Chem. Toxicol. 39: 361-366.

Singh, R., Agarwal, R. A. and Bhutani, D. K. 1986. Control of pink bollworm, in cotton seed through insecticidal treatment. Seed Res. (New Delhi) 14: 60-65.

Suresh, S. and Regupathy, A. 1986. Toxicity of insecticides to banana aphid (Pentalonia nigronervosa). Indian J. Agric. Sci. 56: 200-203.

Tripathy, N. K. and Patnaik, K. K. 1992. Studies on the gentoxicity of "Monocrotophos" in somatic and germ-like cells of Drosophila. Mutat. Res. 278: 23-29.

Varma, A., Somadder, K. and Kishore, R. 1978. Biology bionomics and control of Melan aphis indosaccharia David, a vactor of sugarcane grassy shoot disease. Indian J. Agric. Res. 12: 65-72.

Wang, T. C., Lee, T. C., Lin, M. F. and Lin, S. Y. 1987. Induction of sister chromatid exchanges by pesticides in primary rat tracheal epithelial cells and Chinese hamster ovary cells. Mutat. Res. 188: 311-321. 